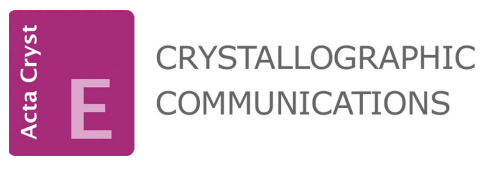

ISSN 2056-9890

Received 17 July 2019

Accepted 18 July 2019

Edited by W. T. A. Harrison, University of Aberdeen, Scotland

₹ Additional correspondence author, e-mail: julio@power.ufscar.br.

Keywords: crystal structure; acetylene; hydrogen bonding; Hirshfeld surface analysis; $\mathrm{NCl}$ plots; computational chemistry.

CCDC reference: 1941466

Supporting information: this article has supporting information at journals.iucr.org/e

\section{2-Methyl-4-(4-nitrophenyl)but-3-yn-2-ol: crystal structure, Hirshfeld surface analysis and computational chemistry study}

\author{
Ignez Caracelli, ${ }^{a}$ Julio Zukerman-Schpector, ${ }^{b} \neq$ Ricardo S. Schwab, ${ }^{b}$ Everton M. da \\ Silva, ${ }^{\text {b }}$ Mukesh M. Jotani ${ }^{\mathrm{c}}$ and Edward R. T. Tiekink ${ }^{\mathrm{d}}$ *
}

\author{
aDepartamento de Física, Universidade Federal de São Carlos, 13565-905 São Carlos, SP, Brazil, 'bepartamento de \\ Química, Universidade Federal de São Carlos, 13565-905 São Carlos, SP, Brazil, 'Department of Physics, Bhavan's Sheth \\ R. A. College of Science, Ahmedabad, Gujarat 380001, India, and ${ }^{\mathbf{d}}$ Research Centre for Crystalline Materials, School of \\ Science and Technology, Sunway University, 47500 Bandar Sunway, Selangor Darul Ehsan, Malaysia. *Correspondence \\ e-mail: edwardt@sunway.edu.my
}

The di-substituted acetylene residue in the title compound, $\mathrm{C}_{11} \mathrm{H}_{11} \mathrm{NO}_{3}$, is capped at either end by di-methylhydroxy and 4-nitrobenzene groups; the nitro substituent is close to co-planar with the ring to which it is attached [dihedral angle $\left.=9.4(3)^{\circ}\right]$. The most prominent feature of the molecular packing is the formation, via hydroxy- $\mathrm{O}-\mathrm{H} \cdots \mathrm{O}$ (hydroxy) hydrogen bonds, of hexameric clusters about a site of symmetry $\overline{3}$. The aggregates are sustained by $12-$ membered $\{\cdots \mathrm{OH}\}_{6}$ synthons and have the shape of a flattened chair. The clusters are connected into a three-dimensional architecture by benzene- $\mathrm{C}-$ $\mathrm{H}$. . O (nitro) interactions, involving both nitro-O atoms. The aforementioned interactions are readily identified in the calculated Hirshfeld surface. Computational chemistry indicates there is a significant energy, primarily electrostatic in nature, associated with the hydroxy-O $-\mathrm{H} \cdots \mathrm{O}$ (hydroxy) hydrogen bonds. Dispersion forces are more important in the other identified but, weaker intermolecular contacts.

\section{Chemical context}

Protected acetylenes represent a highly privileged class of synthetic intermediates for the construction of a variety of different organic compounds (Tan et al., 2013). The preparation of protected arylacetylenes can be achieved by the palladium-catalysed Sonogashira cross-coupling of monoprotected acetylenes, such as trimethylsilylacetylene (TMSA), triisopropysilylacetylene (TIPSA) and 2-methyl-3-butyn-2-ol (MEBYNOL), with aryl halides (Hundertmark et al., 2000; Erdélyi \& Gogoll, 2001). Despite the relevance of protected acetylenes, the release of the protecting group remains a challenge. While trialkylsilyl groups can be readily removed by treatment with bases or fluoride salts under mild reaction conditions, trialkylsilylacetylenes are rather expensive, in comparison to MEYBNOL, thereby limiting their use to small-scale synthesis. Thus, MEBYNOL can be viewed as one alternative to other acetylene sources. Nevertheless, the reaction conditions for the release of the 2-hydroxyisopropyl protecting group usually requires harsh reaction conditions. Hence, several synthetic routes combine the release of the terminal acetylene with a further transformation, without the isolation of the intermediate ( $\mathrm{Li}$ et al., 2015). It was in the context of such considerations that the title acetylene 
compound, (I), previously reported (Bleicher et al., 1998), was isolated and crystallized. Herein, the crystal and molecular structures of (I) are described along with a detailed analysis of the molecular packing by Hirshfeld surface analysis, noncovalent interaction plots and computational chemistry.

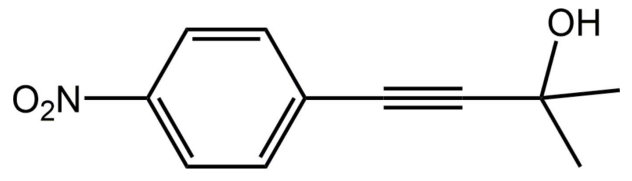

\section{Structural commentary}

The molecular structure of (I), Fig. 1, features a di-substituted acetylene residue. At one end, the acetylene terminates with a di-methylhydroxy substituent and at the other end, with a 4-nitrobenzene group. The nitro group is slightly inclined out of the plane of the benzene ring to which it is connected, with the dihedral angle between the planes being $9.4(3)^{\circ}$.

\section{Supramolecular features}

The spectacular feature of the molecular packing of (I) is the presence of hexameric clusters connected by hydroxy-O$\mathrm{H}$... O (hydroxy) hydrogen bonds, Table 1. As seen from Fig. 2(a), the six-molecule aggregates are sustained by 12membered $\{\cdots \mathrm{OH}\}_{6}$ synthons. The aggregates are disposed about a site of symmetry $\overline{3}$ so the rings have the shape of a flattened chair, Fig. 2(b). The crystal also features weak benzene- $\mathrm{C}-\mathrm{H} \cdots \mathrm{O}$ (nitro) interactions, involving both nitro-O atoms. In essence, one nitro group of one molecule forms two such interactions with two symmetry-related molecules to form a supramolecular chain along the $c$-axis direction with helical symmetry ( $3_{1}$ screw axis), Fig. 3(a). An end-on view of the chain is shown in Fig. 3(b). These weak benzene-C$\mathrm{H}$.. O (nitro) interactions serve to link the six-molecule aggregates into a three-dimensional architecture, Fig. 4.

\section{Hirshfeld surface analysis}

The Hirshfeld surface calculations for (I) were performed in accord with protocols described in a recently published paper (Tan et al., 2019) employing Crystal Explorer 17 (Turner et al., 2017). On the Hirshfeld surfaces mapped over $d_{\text {norm }}$ in

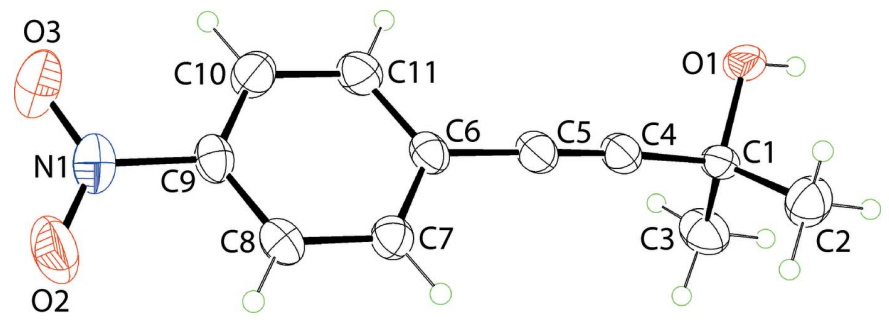

Figure 1

The molecular structure of (I), showing the atom-labelling scheme and displacement ellipsoids at the $35 \%$ probability level.
Table 1

Hydrogen-bond geometry $\left(\AA{ }^{\circ}\right)$.

\begin{tabular}{lllll}
\hline$D-\mathrm{H} \cdots A$ & $D-\mathrm{H}$ & $\mathrm{H} \cdots A$ & $D \cdots A$ & $D-\mathrm{H} \cdots A$ \\
\hline $\mathrm{O} 1-\mathrm{H} 1 O \cdots \mathrm{O} 1^{\mathrm{i}}$ & 0.82 & 1.87 & $2.682(2)$ & 173 \\
$\mathrm{C} 10-\mathrm{H} 10 \cdots 3^{\mathrm{ii}}$ & 0.93 & 2.67 & $3.548(3)$ & 157 \\
$\mathrm{C} 11-\mathrm{H} 11 \cdots \mathrm{O} 2^{\mathrm{iii}}$ & 0.93 & 2.68 & $3.467(3)$ & 143
\end{tabular}

Symmetry codes: (i) $x-y+\frac{1}{3}, x-\frac{1}{3},-z+\frac{5}{3}$; (ii) $-x+y+\frac{2}{3},-x+\frac{4}{3}, z+\frac{1}{3}$; (iii) $-y+\frac{4}{3}, x-y+\frac{2}{3}, z+\frac{2}{3}$.

Fig. 5(a), the donors and acceptors of $\mathrm{O}-\mathrm{H} \cdots \mathrm{O}$ hydrogen bond involving the atoms of the hydroxyl group are characterized as bright-red spots. The faint-red spots near the phenyl-H10, H11 and nitro-O2, O3 atoms on the $d_{\text {norm }^{-}}$ mapped Hirshfeld surface in Fig. 5(b) represent the effect of
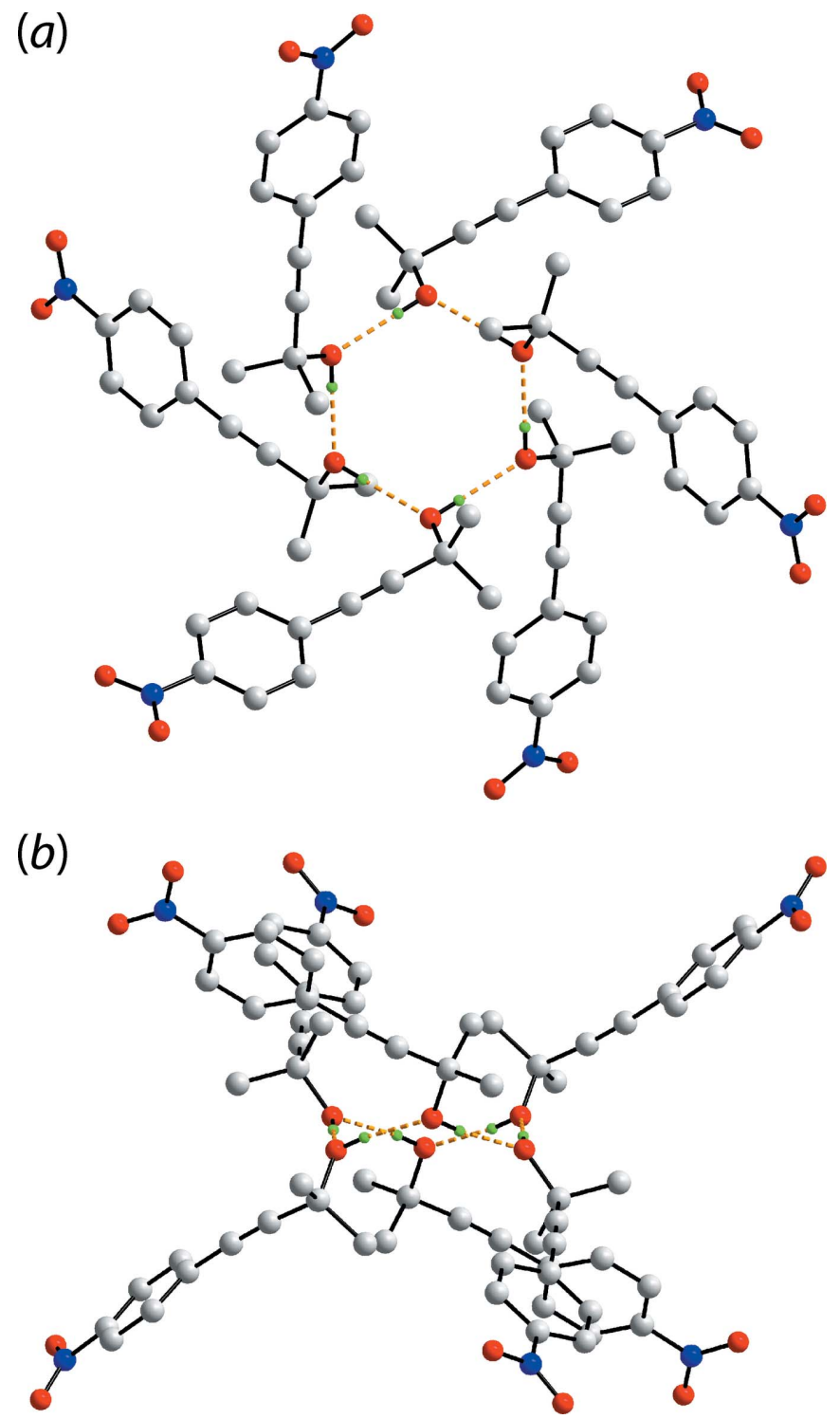

Figure 2

Hydrogen bonding in the crystal of (I): (a) an end-on view of the hexagon sustained by hydroxy- $\mathrm{O}-\mathrm{H} \cdots \mathrm{O}$ (hydroxy) hydrogen bonding (shown as orange dashed lines) and $(b)$ a side-on view. Non-participating hydrogen atoms have been removed for reasons of clarity. 
(a)

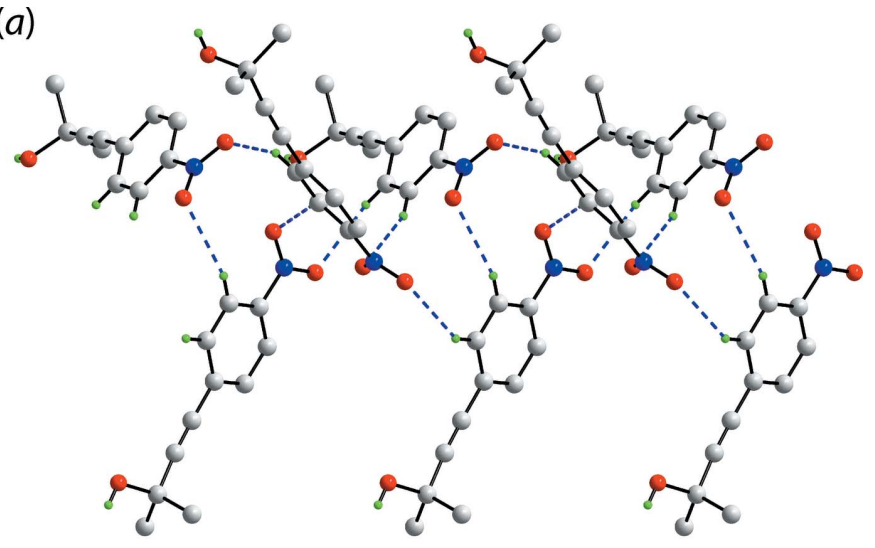

(b)

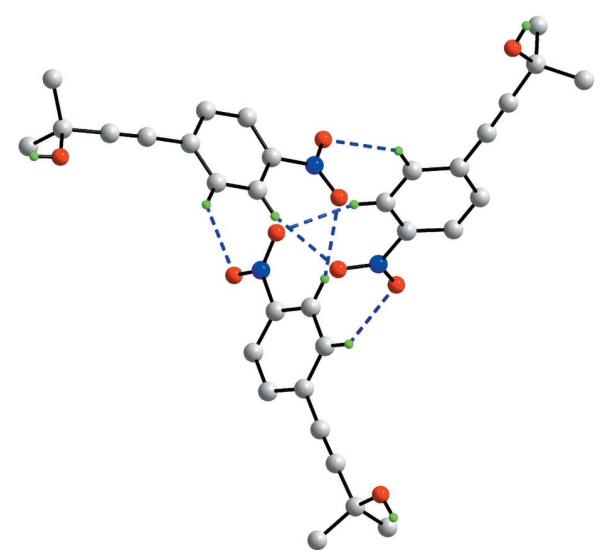

Figure 3

Details of benzene-C-H. O (nitro) interactions (shown as blue dashed lines) in the crystal of (I): (a) a view of the supramolecular chain along the $c$-axis direction and $(b)$ an end-on view of the chain.

weak $\mathrm{C}-\mathrm{H} \cdots \mathrm{O}$ interactions as listed in Table 1. The Hirshfeld surface mapped over electrostatic potential in Fig. 6 also illustrates the donors and acceptors of the indicated interactions through blue and red regions corresponding to positive and negative electrostatic potentials, respectively. In the view

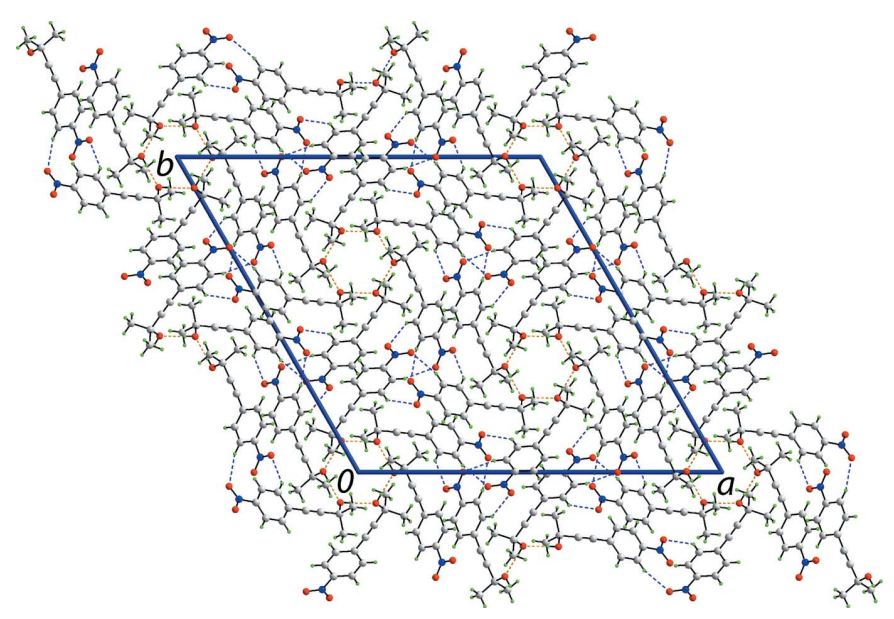

Figure 4

A view of the unit-cell contents of (I) shown in projection down the $c$ axis. The hydroxy- $\mathrm{O}-\mathrm{H} \cdots \mathrm{O}$ (hydroxy) hydrogen bonding and benzene- $\mathrm{C}-$ $\mathrm{H}$... $\mathrm{O}$ (nitro) interactions are shown as orange and blue dashed lines, respectively.

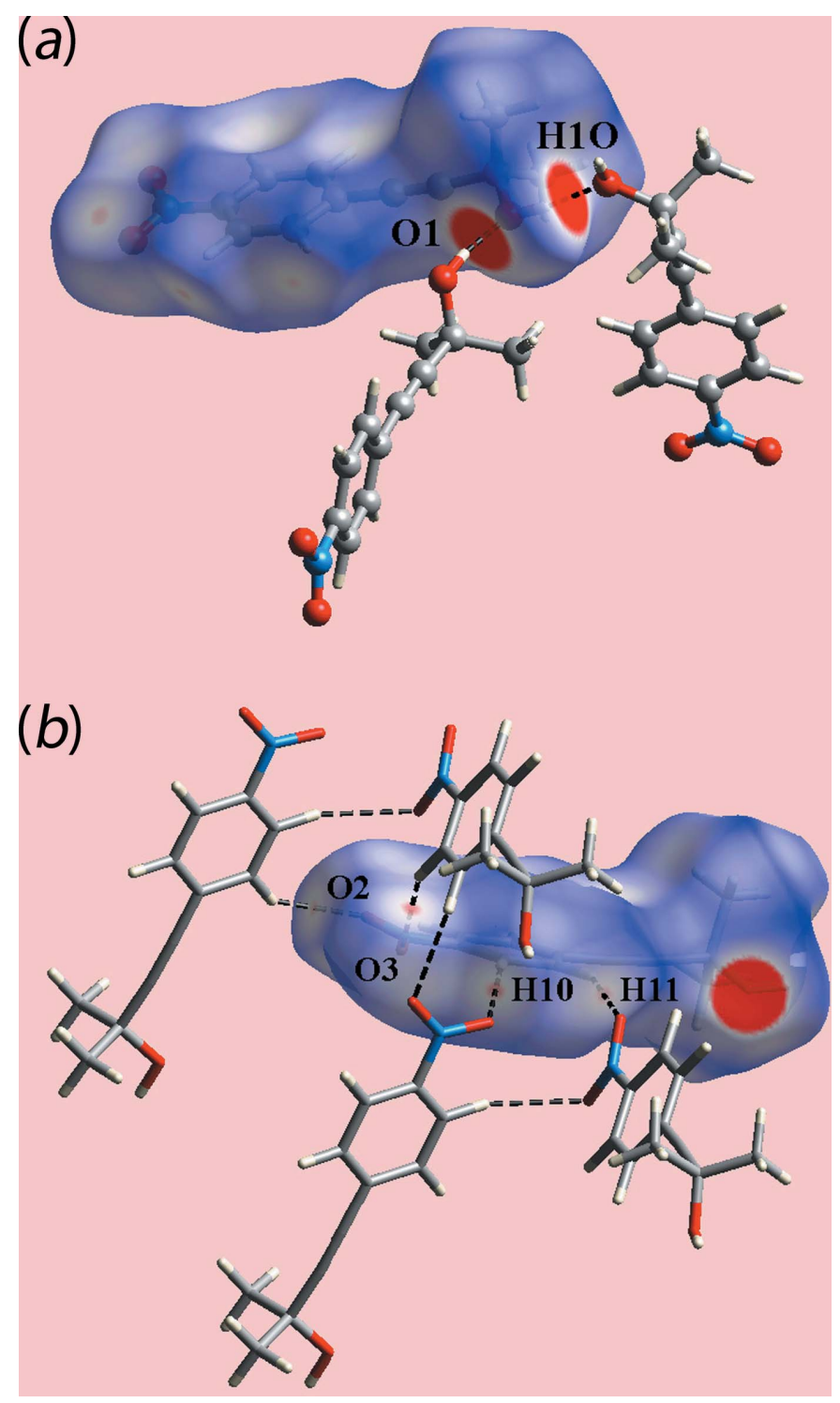

Figure 5

Two views of the Hirshfeld surface for (I) mapped over $d_{\text {norm }}$ : $(a)$ in the range -0.202 to +1.400 arbitrary units and $(b)$ in the range -0.102 to +1.400 arbitrary units, highlighting, respectively, intermolecular $\mathrm{O}-$ $\mathrm{H} \cdots \mathrm{O}$ and $\mathrm{C}-\mathrm{H} \cdots \mathrm{O}$ interactions through black dashed lines.

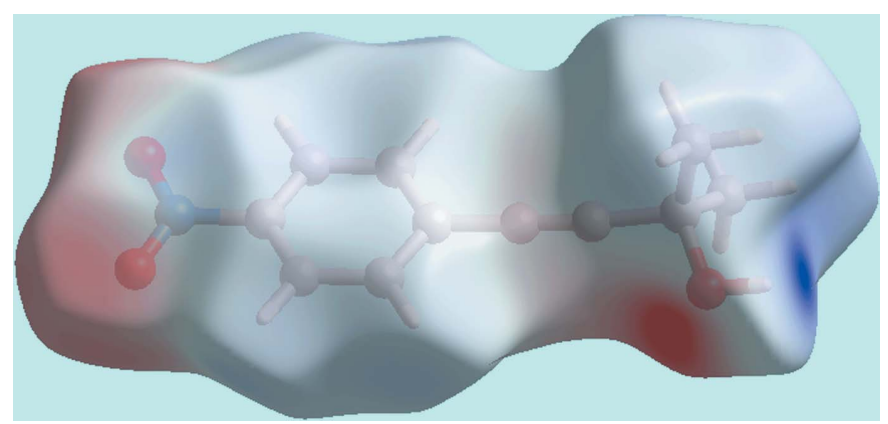

Figure 6

A view of the Hirshfeld surface for (I) mapped over the electrostatic potential in the range -0.098 to +0.180 atomic units. The red and blue regions represent negative and positive electrostatic potentials, respectively, and show the acceptors and donors of intermolecular interactions, respectively. 
Table 2

Summary of short interatomic contacts $(\AA)$ in (I).

The interatomic distances are calculated in Crystal Explorer 17 (Turner et al., 2017) whereby the $X-\mathrm{H}$ bond lengths are adjusted to their neutron values.

\begin{tabular}{lll}
\hline Contact & Distance & Symmetry operation \\
\hline $\mathrm{O} 1 \cdots \mathrm{H} 3 A$ & 2.71 & $\frac{1}{3}+y, \frac{2}{3}-x+y, \frac{5}{3}-z$ \\
$\mathrm{O} 2 \cdots \mathrm{H} 2 B$ & 2.69 & $\frac{2}{3}-y, \frac{1}{3}+x-y,-\frac{2}{3}+z$ \\
$\mathrm{O} 3 \cdots \mathrm{H} 2 A$ & 2.69 & $1-x, 1-y, 1-z$ \\
$\mathrm{C} 1 \cdots \mathrm{H} 1 O$ & 2.85 & $\frac{1}{3}+y, \frac{2}{3}-x+y, \frac{5}{3}-z$ \\
$\mathrm{C} 5 \cdots \mathrm{H} 3 C$ & 2.79 & $\frac{1}{3}+y, \frac{2}{3}-x+y, \frac{2}{3}-z$ \\
$\mathrm{C} 7 \cdots \mathrm{H} 2 C$ & 2.85 & $\frac{1}{3}+y, \frac{2}{3}-x+y, \frac{2}{3}-z$ \\
$\mathrm{C} 8 \cdots \mathrm{H} 2 C$ & 2.80 & $\frac{1}{3}+y, \frac{2}{3}-x+y, \frac{2}{3}-z$ \\
\hline
\end{tabular}

of a surface mapped with the shape-index property, Fig. 7(a), the $\mathrm{C}-\mathrm{H} \cdots \pi / \pi \cdots \mathrm{H}-\mathrm{C}$ contacts listed in Table 2 are evident as the blue bump and a bright-orange region about the participating atoms. The overlap between benzene (C6-C11) ring of a reference molecule within the Hirshfeld surface mapped over curvedness and the symmetry related ring,
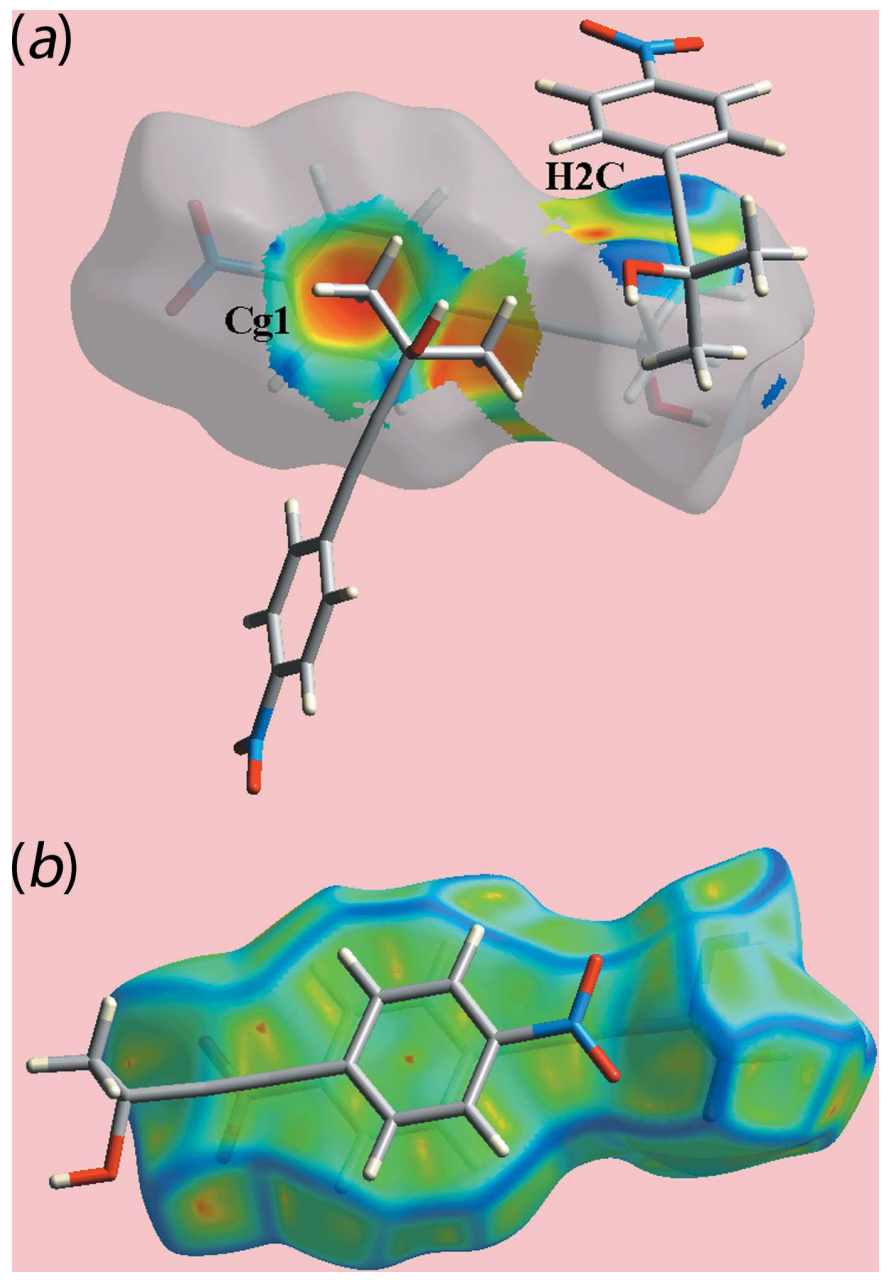

\section{Figure 7}

(a) A view of the Hirshfeld surface for (I) mapped with the shape-index property, highlighting intermolecular $\mathrm{C}-\mathrm{H} \cdots \pi / \pi \cdots \mathrm{H}-\mathrm{C}$ contacts by blue bumps and bright-orange concave regions, respectively, and (b) a view of the Hirshfeld surface mapped over curvedness, highlighting $\pi-\pi$ contacts between symmetry-related (C6-C11) rings.
Table 3

Percentage contributions of interatomic contacts to the Hirshfeld surface for (I).

\begin{tabular}{ll}
\hline Contact & Percentage contribution \\
\hline $\mathrm{H} \cdots \mathrm{H}$ & 38.2 \\
$\mathrm{O} \cdots \mathrm{H} / \mathrm{H} \cdots \mathrm{O}$ & 32.1 \\
$\mathrm{C} \cdots \mathrm{H} / \mathrm{H} \cdots \mathrm{C}$ & 20.0 \\
$\mathrm{C} \cdots \mathrm{C}$ & 4.2 \\
$\mathrm{~N} \cdots \mathrm{O} / \mathrm{O} \cdots \mathrm{N}$ & 1.7 \\
$\mathrm{O} \cdots \mathrm{O}$ & 1.6 \\
$\mathrm{C} \cdots \mathrm{N} / \mathrm{N} \cdots \mathrm{C}$ & 1.0 \\
$\mathrm{~N} \cdots \mathrm{H} / \mathrm{H} \cdots \mathrm{N}$ & 0.8 \\
$\mathrm{C} \cdots \mathrm{O} / \mathrm{O} \cdots \mathrm{C}$ & 0.4 \\
\hline
\end{tabular}

Fig. $7(b)$ is an indication of the $\pi-\pi$ stacking interaction between them [centroid-centroid distance $=3.7873$ (14) $\AA$; symmetry operation: $1-x, 1-y, 1-z$ ].

The overall two-dimensional fingerprint plot for (I), Fig. $8(a)$, and those delineated into $\mathrm{H} \cdots \mathrm{H}, \mathrm{O} \cdots \mathrm{H} / \mathrm{H} \cdots \mathrm{O}$, $\mathrm{C} \cdots \mathrm{H} / \mathrm{H} \cdots \mathrm{C}$ and $\mathrm{C} \cdots \mathrm{C}$ contacts (McKinnon et al., 2007) are illustrated in Fig. 8(b)-(e), respectively, and provide more information on the influence of short interatomic contacts upon the molecular packing. The percentage contributions from the different interatomic contacts to the Hirshfeld surface are summarized in Table 3 . The greatest contribution to the Hirshfeld surface of $38.2 \%$ are derived from $\mathrm{H} \cdots \mathrm{H}$ contacts but these exert a negligible influence on the packing, at least in terms of directional interactions, as the interatomic distances are greater than sum of their van der Waals radii. The pair of long spikes with their tips at $d_{\mathrm{e}}+d_{\mathrm{i}} \sim 1.8 \AA$ in the fingerprint plot delineated into $\mathrm{O} \cdots \mathrm{H} / \mathrm{H} \cdots \mathrm{O}$ contacts, Fig. $8(\mathrm{c})$, are due to the presence of the $\mathrm{O}-\mathrm{H} \cdots \mathrm{O}$ hydrogen bond, whereas the points corresponding to comparatively weak intermolecular $\mathrm{C}-\mathrm{H} \cdots \mathrm{O}$ interactions, Table 1 , and the short interatomic $\mathrm{O} \cdots \mathrm{H} / \mathrm{H} \cdots \mathrm{O}$ contacts are merged within the plot, Table 2. The presence of the $\mathrm{C}-\mathrm{H} \cdots \pi$ contact, formed by the methyl-H2C atom and the benzene (C6-C11) ring, results in short interatomic $\mathrm{C} \cdots \mathrm{H} / \mathrm{H} \cdots \mathrm{C}$ contacts, Table 2 and Fig. 7(a), and by the pair of forceps-like tips at $d_{\mathrm{e}}+d_{\mathrm{i}} \sim 2.8 \AA$ in Fig. $8(d)$. The points corresponding to other such short interatomic contacts involving the acetylene-C5 and methyl-C $3-\mathrm{H} 3 \mathrm{c}$ atoms at longer separations are merged within the plot. The arrow-shaped distribution of points around $d_{\mathrm{e}}+d_{\mathrm{i}} \sim 3.6 \AA$ in the fingerprint plot delineated into C. . C contacts, Fig. 8(e), indicate $\pi-\pi$ overlap between symmetry-related benzene (C6-C11) rings, as illustrated in Fig. 7(b). The small percentage contributions from the other interatomic contacts listed in Table 3 have negligible influence upon the molecular packing as their separations are greater than the sum of the respective van der Waals radii.

\section{Interaction energies}

The pairwise interaction energies between the molecules within the crystal were calculated by summing up four energy components comprising electrostatic $\left(E_{\text {ele }}\right)$, polarization $\left(E_{\mathrm{pol}}\right)$, dispersion $\left(E_{\mathrm{dis}}\right)$ and exchange-repulsion $\left(E_{\mathrm{rep}}\right)$ terms 
Table 4

Summary of interaction energies $\left(\mathrm{kJ} \mathrm{mol}^{-1}\right)$ calculated for (I).

\begin{tabular}{lcccccc}
\hline Contact & $R(\AA)$ & $E_{\text {ele }}$ & $E_{\text {pol }}$ & $E_{\text {dis }}$ & $E_{\text {rep }}$ & $E_{\text {tot }}$ \\
\hline $\mathrm{O} 1-\mathrm{H} 1 O \cdots \mathrm{O} 1^{\mathrm{i}}$ & & & & & & \\
$\mathrm{H} 3 A \cdots \mathrm{O} 1^{\mathrm{i}}$ & 8.80 & -52.3 & -12.0 & -18.8 & 72.7 & -35.7 \\
$\mathrm{H} 1 O \cdots 1^{\mathrm{i}}$ & & & & & & \\
$\mathrm{C} 10-\mathrm{H} 10 \cdots \mathrm{O} 3^{\mathrm{ii}}$ & 8.28 & -3.7 & -1.4 & -9.2 & 4.9 & -9.8 \\
$\mathrm{C} 11-\mathrm{H} 11 \cdots \mathrm{O} 2^{\mathrm{iii}}$ & 9.51 & -5.8 & -1.7 & -5.7 & 5.0 & -9.6 \\
$\mathrm{O} 3 \cdots \mathrm{H} 2 A^{\mathrm{iv}}$ & & & & & & \\
$(\mathrm{C} 6-\mathrm{C} 11) \cdots(\mathrm{C} 6-\mathrm{C} 11)^{\mathrm{iv}}$ & 4.25 & -9.4 & -1.8 & -47.1 & 28.9 & -34.4 \\
$\mathrm{H} 3 C \cdots \mathrm{C} 5^{\mathrm{v}}$ & & & & & & \\
$\mathrm{H} 2 C \cdots \mathrm{C} 7^{\mathrm{v}}$ & & & & & & \\
$\mathrm{H} 2 C \cdots \mathrm{C} 8^{\mathrm{v}}$ & 5.78 & -2.1 & -0.7 & -28.6 & 18.2 & -16.4 \\
$\mathrm{C} 2-\mathrm{H} 2 C \cdots(\mathrm{C} 6-\mathrm{C} 11)^{\mathrm{v}}$ & & & & & & \\
\hline
\end{tabular}

after applying relevant scale factors (Turner et al., 2017). These energies were obtained by using the wave function calculated at the B3LYP/6-31G(d,p) level. The strength and the nature of intermolecular interactions in terms of their energies are quantitatively summarized in Table 4 . The energies calculated for the different intermolecular interactions indicate that the electrostatic contribution is dominant in the $\mathrm{O}-\mathrm{H} \cdots \mathrm{O}$ hydrogen bond whereas the dispersive component has a significant influence due to the presence of short interatomic $\mathrm{C} \cdots \mathrm{H} / \mathrm{H} \cdots \mathrm{C}$ and $\mathrm{O} \cdots \mathrm{H} / \mathrm{H} \cdots \mathrm{O}$ contacts occurring between the same pair of molecules. The $\mathrm{C}-\mathrm{H} \cdots \mathrm{O} 2$ (nitro) interaction has almost the same contributions from the electrostatic and dispersive components. This is in contrast to a major contribution only from the dispersive component for the analogous contact involving the nitro-O3 atom. The dispersion energy component makes the major contribution to the relevant pairs of molecules involved in other short interatomic contacts, Table 4 , as well as in $\mathrm{C}-\mathrm{H} \cdots \pi$ and $\pi-\pi$ stacking interactions. It is also evident from a comparison of the total energies of intermolecular interactions, Table 4, that the $\mathrm{O}-\mathrm{H} \cdots \mathrm{O}$ hydrogen bond and $\pi-\pi$ stacking interaction are stronger than the other interactions, and, of these, the intermolecular $\mathrm{C}-$ $\mathrm{H} \cdots \mathrm{O}$ contacts are weaker than the $\mathrm{C}-\mathrm{H} \cdots \pi$ interactions.

The magnitudes of intermolecular energies are represented graphically by energy frameworks to view the supramolecular architecture of the crystal through the cylinders joining centroids of molecular pairs by using red, green and blue colour codes for the components $E_{\text {ele }}, E_{\text {disp }}$ and $E_{\text {tot }}$, respectively, Fig. 9. The radius of the cylinder is proportional to the magnitude of interaction energy, which are adjusted to the same scale factor of 30 with a cut-off value of $3 \mathrm{~kJ} \mathrm{~mol}^{-1}$ within $2 \times 2 \times 2$ unit cells.

\section{Non-covalent interaction plots}

Non-covalent interaction plot (NCIplot) analyses provide a visual representation of the nature of the contact between specified species in crystals (Johnson et al., 2010; ContrerasGarcá et al., 2011). This method is based on the electron density (and derivatives) and was employed in the present study to confirm the nature of some of the specified intermolecular contacts. The colour-based isosurfaces generated
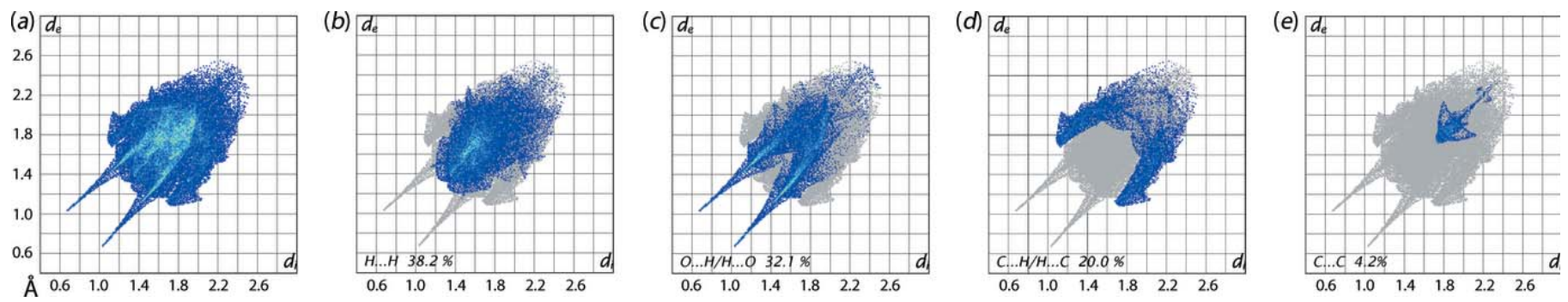

Figure 8

(a) The full two-dimensional fingerprint plot for (I) and $(b)-(e)$ those delineated into $\mathrm{H} \cdots \mathrm{H}, \mathrm{O} \cdots \mathrm{H} / \mathrm{H} \cdots \mathrm{O}, \mathrm{C} \cdots \mathrm{H} / \mathrm{H} \cdots \mathrm{C}$ and $\mathrm{C} \cdots \mathrm{C}$ contacts, respectively.
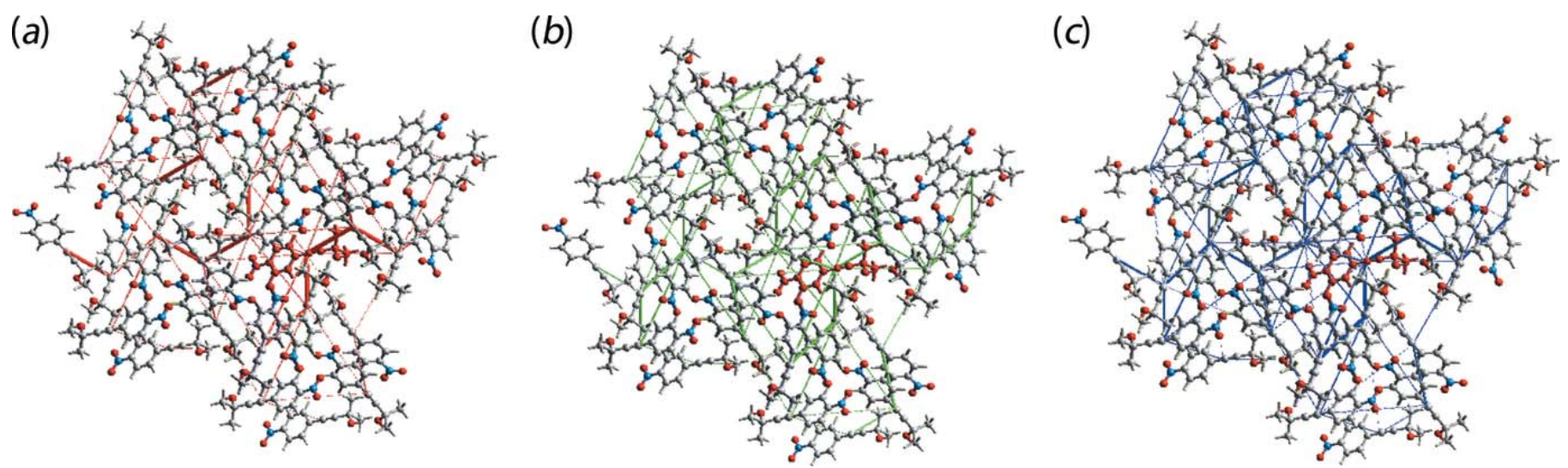

Figure 9

A comparison of the energy frameworks calculated for (I) and viewed down the $c$ axis showing $(a)$ electrostatic potential force, $(b)$ dispersion force and (c) total energy. The energy frameworks were adjusted to the same scale factor of 30 with a cut-off value of $3 \mathrm{~kJ} \mathrm{~mol}^{-1}$ within $2 \times 2 \times 2$ unit cells. 
Table 5

Geometric data $\left(\AA{ }^{\circ}\right)$ for related 2-methyl-4-(aryl)but-3-yn-2-ol molecules.

\begin{tabular}{lllllll}
\hline Compound & $Z^{\prime}$ & $\mathrm{C}_{\text {ring }}-\mathrm{C}_{\text {acetylene }}$ & $\mathrm{C}_{\text {acetylene }}-\mathrm{C}_{\text {acetylene }}$ & $\mathrm{C}_{\text {acetylene }}-\mathrm{C}_{\text {quaternary }}$ & Supramolecular motif & Reference \\
\hline (I) & 1 & $1.438(3)$ & $1.189(3)$ & $1.471(3)$ & hexamer & This work \\
(II) & 3 & $1.443(5)$ & $1.211(5)$ & $1.454(5)$ & chain & Singelenberg \& van Eijck (1987) \\
& & $1.437(6)$ & $1.192(6)$ & $1.479(6)$ & dimer & Clegg (2017) \\
(III) & 2 & $1.437(5)$ & $1.189(5)$ & $1.479(5)$ & \\
& & $1.441(2)$ & $1.193(2)$ & $1.490(2)$ & chain & Eissmann et al. $(2010)$ \\
(IV) & 1 & $1.4377(16)$ & $1.1895(2)$ & $1.2000(16)$ & $1.4791(16)$ & Hübscher et al. $(2016)$ \\
(V) & 3 & $1.4418(18)$ & $1.1951(19)$ & $1.4764(19)$ & \\
& & $1.444(2)$ & $1.194(2)$ & $1.4859(19)$ & \\
\end{tabular}

correspond to the values of $\operatorname{sign}\left(\lambda^{2}\right) \rho(\mathrm{r})$, where $\rho$ is the electron density and $\lambda^{2}$ is the second eigenvalue of the Hessian matrix of $\rho$. Crucially, through a three-colour scheme, a specific interaction can be identified as being attractive or otherwise. Thus, a green isosurface indicates a weakly attractive interaction whereas a blue isosurface indicates an attractive interaction; a repulsive interaction appears red. The isosurfaces for three identified intermolecular interactions are given in the upper view of Fig. 10. Thus, in Fig. 10(a), a green isosurface is apparent for the conventional hydroxy-O$\mathrm{H}$... O (hydroxy) hydrogen bond. Similarly, green isosurfaces are seen between the interacting atoms involved in the phenyl$\mathrm{C}-\mathrm{H} \cdots \mathrm{O}$ (nitro), Fig. $10(b)$, and the methyl-C $-\mathrm{H} \cdots \pi(\mathrm{C} 11-$ C16), Fig. 10(c), interactions.

The lower views of Fig. 10, show the plots of the RDG versus $\operatorname{sign}\left(\lambda^{2}\right) \rho(\mathrm{r})$. The non-covalent interaction peaks appear at density values less than 0.0 atomic units, consistent with their being weakly attractive interactions.

\section{Database survey}

There are four literature precedents for (I) with varying substitution patterns in the appended benzene ring. These are the unsubstituted 'parent' compound [(II); FESMEV; Singelenberg \& van Eijck, 1987], and the 4-cyano [(III\}; HEFDAA; Clegg, 2017], 4-methoxy [(IV); YUQPEG; Eissmann et al., 2010] and 3-acetyl-4-hydroxy [(V); UVETAS; Hübscher et al., 2016] derivatives. Selected geometric parameters for (I)-(IV)
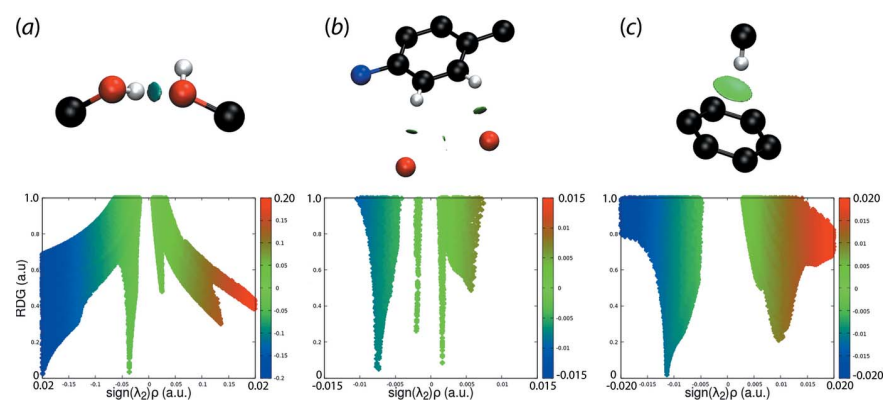

Figure 10

Non-covalent interaction plots for (a) hydroxy-O-H $\cdots \mathrm{O}$ (hydroxy) hydrogen bonding, $(b)$ the phenyl- $\mathrm{C}-\mathrm{H} \cdots \mathrm{O}$ (nitro) interactions and $(c)$ the methyl-C $-\mathrm{H} \cdots \pi(\mathrm{C} 11-\mathrm{C} 16)$ interactions. are collated in Table 5. Of particular interest in the mode of supramolecular association in their crystals. As seen from Fig. 11, four distinct patterns appear. In (V), three independent molecules comprise the asymmetric unit and these associate about a centre of inversion in space group $P 2_{1} / c$ to form a hexameric clusters via hydroxy-O $-\mathrm{H} \cdots \mathrm{O}$ (hydroxy) hydrogen bonds as seen in (I), Fig. 11(a); intramolecular hydroxy-O-H... (carbonyl) hydrogen bonds are also apparent. In (III), the two independent molecules comprising the asymmetric unit associate about a centre of inversion in space group $P 2_{1} / n$ into a supramolecular dimer via pairs of hydroxy-O $-\mathrm{H} \cdots \mathrm{O}$ (hydroxy) and hydroxy-O $-\mathrm{H} \cdots \mathrm{N}$ (cyano) hydrogen bonds as shown in Fig. 11(b). In this case, one independent hydroxy-oxygen atom and one cyano-nitrogen atom do not accept a hydrogen-bonding interaction. Three crystallographically independent molecules are also found in (II) (space group $\mathrm{Pca}_{1}$ ) and these self-associate to form a (a)

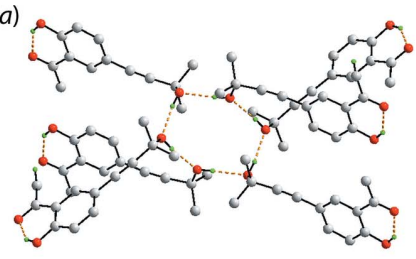

(c)

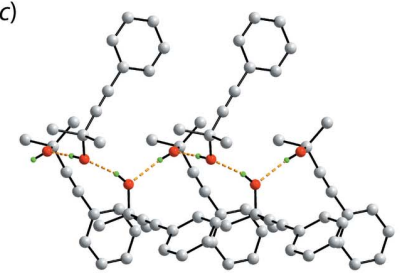

$(d)$

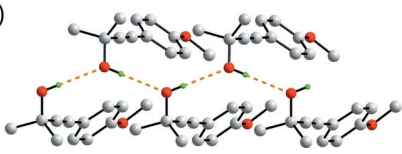

(b)
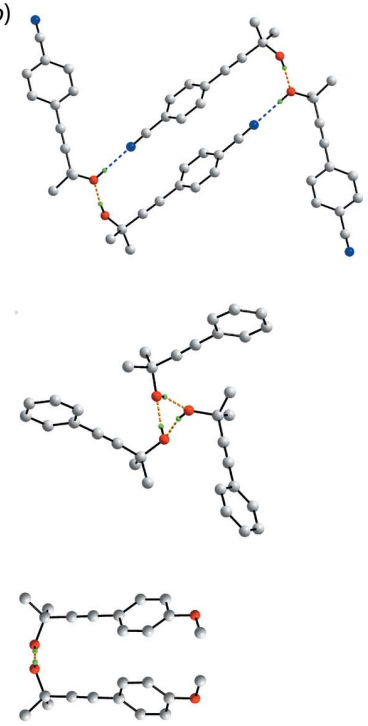

Figure 11

Supramolecular association via hydroxy-O - H - . O (hydroxy) hydrogen bonds in (II)-(IV): (a) hexameric cluster in (V), (b) dimeric aggregate sustained by additional hydroxy-O $-\mathrm{H} \cdots \mathrm{N}$ (cyano) hydrogen bonds in (III), (c) views of the supramolecular chain in (II) with non-crystallographic threefold symmetry and $(d)$ views of the zigzag supramolecular chain in (IV). 
supramolecular chain via hydroxy-O-H $-\mathrm{H}$ O(hydroxy) hydrogen bonds with non-crystallographic threefold symmetry, Fig. 11(c). Finally, zigzag supramolecular chains sustained by hydroxy-O $-\mathrm{H} \cdots \mathrm{O}$ (hydroxy) hydrogen bonds are found in the crystal of (IV), Fig. 11(d) in space group Pbca.

\section{Synthesis and crystallization}

The title compound was prepared as per the literature procedure (Bleicher et al., 1998). Yield: 87\%. Yellow solid, m.p. $377-379 \mathrm{~K} .{ }^{1} \mathrm{H}$ NMR $\left(400 \mathrm{MHz}, \mathrm{CDCl}_{3}\right): \delta=8.16(d t, J=$ $8.9,2.2 \mathrm{~Hz}, 2 \mathrm{H}), 7.54(d t, J=8.9,2.2 \mathrm{~Hz}, 2 \mathrm{H}), 2.24(s, 1 \mathrm{H})$ and $1.63(s, 6 \mathrm{H})$ ppm. ${ }^{13} \mathrm{C}$ NMR $\left(101 \mathrm{MHz}, \mathrm{CDCl}_{3}\right): \delta=147.2$, $132.5,129.8,123.6,99.2,80.5,66.7$ and $31.3 \mathrm{ppm}$. Irregular colourless crystals of (I) for the X-ray study were grown by slow evaporation of its ethyl acetate solution.

\section{Refinement details}

Crystal data, data collection and structure refinement details are summarized in Table 6 . The carbon-bound $\mathrm{H}$ atoms were placed in calculated positions $(\mathrm{C}-\mathrm{H}=0.93-0.96 \AA)$ and were included in the refinement in the riding-model approximation, with $U_{\text {iso }}(\mathrm{H})$ set to $1.2-1.5 U_{\text {eq }}(\mathrm{C})$. The $\mathrm{O}$-bound $\mathrm{H}$ atom was refined with a distance restraint of $0.82 \pm 0.01 \AA$, and with $U_{\text {iso }}(\mathrm{H})=1.5 U_{\text {eq }}(\mathrm{O})$.

\section{Acknowledgements}

We thank Professor Regina H. A. Santos from IQSC-USP for the X-ray data collection.

\section{Funding information}

Funding for this research was provided by GlaxoSmithKline (GSK) and the Brazilian agencies: The National Council for Scientific and Technological Development are thanked for fellowships (CNPq: 308480/2016-3 to IC; 303207/2017-5 to JZS), São Paulo Research Foundation (FAPESP, grants 2013/ 06558-3 and 2014/50249-8) and Coordenação de Aperfeiçoamento de Pessoal de Nível Superior - Brasil (CAPES) Finance Code 001. Sunway University Sdn Bhd is also thanked for funding (grant No. STR-RCTR-RCCM-001-2019).

\section{References}

Bleicher, L. S., Cosford, N. D. P., Herbaut, A., McCallum, J. S. \& McDonald, I. A. (1998). J. Org. Chem. 63, 1109-1118.

Brandenburg, K. (2006). DIAMOND. Crystal Impact GbR, Bonn, Germany.

Bruker (2009). APEX2 and SAINT. Bruker AXS Inc., Madison, Wisconsin, USA.

Burla, M. C., Caliandro, R., Carrozzini, B., Cascarano, G. L., Cuocci, C., Giacovazzo, C., Mallamo, M., Mazzone, A. \& Polidori, G. (2015). J. Appl. Cryst. 48, 306-309.

ChemAxon (2010). Marvinsketch. http://www.chemaxon.com.

Clegg, W. (2017). Private communication (refcode: HEFDAA). CCDC, Cambridge, England.
Table 6

Experimental details.

\begin{tabular}{|c|c|}
\hline \multicolumn{2}{|l|}{ Crystal data } \\
\hline Chemical formula & $\mathrm{C}_{11} \mathrm{H}_{11} \mathrm{NO}_{3}$ \\
\hline$M_{\mathrm{r}}$ & 205.21 \\
\hline Crystal system, space group & Trigonal, $R \overline{3}: H$ \\
\hline Temperature $(\mathrm{K})$ & 296 \\
\hline$a, c(\AA)$ & $26.3146(14), 8.1205(5)$ \\
\hline$V\left(\AA^{3}\right)$ & $4869.8(6)$ \\
\hline$Z$ & 18 \\
\hline Radiation type & Mo $K \alpha$ \\
\hline$\mu\left(\mathrm{mm}^{-1}\right)$ & 0.09 \\
\hline Crystal size $(\mathrm{mm})$ & $0.34 \times 0.28 \times 0.16$ \\
\hline \multicolumn{2}{|l|}{ Data collection } \\
\hline Diffractometer & Bruker APEXII CCD \\
\hline Absorption correction & $\begin{array}{l}\text { Multi-scan (SADABS; Sheldrick, } \\
\text { 1996) }\end{array}$ \\
\hline$T_{\min }, T_{\max }$ & $0.440,0.745$ \\
\hline $\begin{array}{l}\text { No. of measured, independent and } \\
\text { observed }[I>2 \sigma(I)] \text { reflections }\end{array}$ & $10643,2230,1513$ \\
\hline$R_{\text {int }}$ & 0.080 \\
\hline$(\sin \theta / \lambda)_{\max }\left(\AA^{-1}\right)$ & 0.627 \\
\hline \multicolumn{2}{|l|}{ Refinement } \\
\hline$R\left[F^{2}>2 \sigma\left(F^{2}\right)\right], w R\left(F^{2}\right), S$ & $0.053,0.149,1.05$ \\
\hline No. of reflections & 2230 \\
\hline No. of parameters & 139 \\
\hline No. of restraints & 1 \\
\hline $\mathrm{H}$-atom treatment & H-atom parameters constrained \\
\hline$\Delta \rho_{\max }, \Delta \rho_{\min }\left(\mathrm{e} \AA^{-3}\right)$ & $0.16,-0.27$ \\
\hline
\end{tabular}

Computer programs: APEX2 and SAINT (Bruker, 2009), SIR2014 (Burla et al., 2015), SHELXL2018/3 (Sheldrick, 2015), ORTEP-3 for Windows (Farrugia, 2012), DIAMOND (Brandenburg, 2006), MarvinSketch (ChemAxon, 2010) and publCIF (Westrip, 2010).

Contreras-García, J., Johnson, E. R., Keinan, S., Chaudret, R., Piquemal, J.-P., Beratan, D. N. \& Yang, W. (2011). J. Chem. Theory Comput. 7, 625-632.

Eissmann, F., Kafurke, U. \& Weber, E. (2010). Acta Cryst. E66, o1866.

Erdélyi, M. \& Gogoll, A. (2001). J. Org. Chem. 66, 4165-4169.

Farrugia, L. J. (2012). J. Appl. Cryst. 45, 849-854.

Hübscher, J., Rosin, R., Seichter, W. \& Weber, E. (2016). Acta Cryst. E72, 1370-1373.

Hundertmark, T., Littke, A. F., Buchwald, S. L. \& Fu, G. C. (2000). Org. Lett. 2, 1729-1731.

Johnson, E. R., Keinan, S., Mori-Sánchez, P., Contreras-García, J., Cohen, A. J. \& Yang, W. (2010). J. Am. Chem. Soc. 132, 64986506.

Li, X., Sun, S., Yang, F., Kang, J., Wu, Y. \& Wu, Y. (2015). Org. Biomol. Chem. 13, 2432-2436.

McKinnon, J. J., Jayatilaka, D. \& Spackman, M. A. (2007). Chem. Commun. pp. 3814-3816.

Sheldrick, G. M. (1996). SADABS. University of Göttingen, Germany.

Sheldrick, G. M. (2015). Acta Cryst. C71, 3-8

Singelenberg, F. A. J. \& van Eijck, B. P. (1987). Acta Cryst. C43, $693-$ 695.

Tan, S. L., Jotani, M. M. \& Tiekink, E. R. T. (2019). Acta Cryst. E75, 308-318.

Tan, X., Kong, L., Dai, H., Cheng, X., Liu, F. \& Tschierske, C. (2013). Chem. Eur. J. 19, 16303-16313.

Turner, M. J., Mckinnon, J. J., Wolff, S. K., Grimwood, D. J., Spackman, P. R., Jayatilaka, D. \& Spackman, M. A. (2017). Crystal Explorer 17. The University of Western Australia.

Westrip, S. P. (2010). J. Appl. Cryst. 43, 920-925. 


\section{supporting information}

Acta Cryst. (2019). E75, 1232-1238 [https://doi.org/10.1107/S2056989019010284]

\section{2-Methyl-4-(4-nitrophenyl) but-3-yn-2-ol: crystal structure, Hirshfeld surface analysis and computational chemistry study}

Ignez Caracelli, Julio Zukerman-Schpector, Ricardo S. Schwab, Everton M. da Silva, Mukesh M. Jotani and Edward R. T. Tiekink

Computing details

Data collection: APEX2 (Bruker, 2009); cell refinement: SAINT (Bruker, 2009); data reduction: SAINT (Bruker, 2009); program(s) used to solve structure: SIR2014 (Burla et al., 2015); program(s) used to refine structure: SHELXL2018/3 (Sheldrick, 2015); molecular graphics: ORTEP-3 for Windows (Farrugia, 2012), DIAMOND (Brandenburg, 2006); software used to prepare material for publication: MarvinSketch (ChemAxon, 2010) and publCIF (Westrip, 2010).

2-Methyl-4-(4-nitrophenyl)but-3-yn-2-ol

Crystal data

$\mathrm{C}_{11} \mathrm{H}_{11} \mathrm{NO}_{3}$

$M_{r}=205.21$

Trigonal, $R \overline{3}: H$

$a=26.3146$ (14) $\AA$

$c=8.1205(5) \AA$

$V=4869.8(6) \AA^{3}$

$Z=18$

$F(000)=1944$

Data collection

Bruker APEXII CCD

diffractometer

$\varphi$ and $\omega$ scans

Absorption correction: multi-scan

(SADABS; Sheldrick, 1996)

$T_{\text {min }}=0.440, T_{\max }=0.745$

10643 measured reflections

Refinement

Refinement on $F^{2}$

Least-squares matrix: full

$R\left[F^{2}>2 \sigma\left(F^{2}\right)\right]=0.053$

$w R\left(F^{2}\right)=0.149$

$S=1.05$

2230 reflections

139 parameters

1 restraint

Primary atom site location: structure-invariant direct methods
$D_{\mathrm{x}}=1.260 \mathrm{Mg} \mathrm{m}^{-3}$

Mo $K \alpha$ radiation, $\lambda=0.71073 \AA$

Cell parameters from 2006 reflections

$\theta=2.7-23.9^{\circ}$

$\mu=0.09 \mathrm{~mm}^{-1}$

$T=296 \mathrm{~K}$

Irregular, colourles

$0.34 \times 0.28 \times 0.16 \mathrm{~mm}$

2230 independent reflections

1513 reflections with $I>2 \sigma(I)$

$R_{\text {int }}=0.080$

$\theta_{\text {max }}=26.4^{\circ}, \theta_{\text {min }}=1.6^{\circ}$

$h=-32 \rightarrow 32$

$k=-32 \rightarrow 32$

$l=-9 \rightarrow 10$

Secondary atom site location: difference Fourier map

Hydrogen site location: inferred from neighbouring sites

$\mathrm{H}$-atom parameters constrained

$w=1 /\left[\sigma^{2}\left(F_{\mathrm{o}}^{2}\right)+(0.0511 P)^{2}+3.9317 P\right]$

where $P=\left(F_{\mathrm{o}}^{2}+2 F_{\mathrm{c}}^{2}\right) / 3$

$(\Delta / \sigma)_{\max }<0.001$

$\Delta \rho_{\max }=0.16 \mathrm{e} \AA^{-3}$

$\Delta \rho_{\min }=-0.27 \mathrm{e} \AA^{-3}$ 


\section{Special details}

Geometry. All esds (except the esd in the dihedral angle between two 1.s. planes) are estimated using the full covariance matrix. The cell esds are taken into account individually in the estimation of esds in distances, angles and torsion angles; correlations between esds in cell parameters are only used when they are defined by crystal symmetry. An approximate (isotropic) treatment of cell esds is used for estimating esds involving l.s. planes.

Fractional atomic coordinates and isotropic or equivalent isotropic displacement parameters $\left(\hat{A}^{2}\right)$

\begin{tabular}{lllll}
\hline & $x$ & $y$ & $z$ & $U_{\text {iso }} / U_{\mathrm{eq}}$ \\
\hline $\mathrm{O} 1$ & $0.56993(7)$ & $0.33529(6)$ & $0.78650(17)$ & $0.0513(4)$ \\
$\mathrm{H} 1 \mathrm{O}$ & 0.569241 & 0.305973 & 0.823659 & $0.077^{*}$ \\
$\mathrm{O} 2$ & $0.54778(9)$ & $0.61319(8)$ & $0.0578(2)$ & $0.0811(6)$ \\
$\mathrm{O} 3$ & $0.62154(8)$ & $0.66736(8)$ & $0.2126(3)$ & $0.0785(6)$ \\
$\mathrm{N} 1$ & $0.58062(9)$ & $0.61978(9)$ & $0.1723(3)$ & $0.0565(5)$ \\
$\mathrm{C} 1$ & $0.53437(9)$ & $0.31996(8)$ & $0.6425(2)$ & $0.0388(5)$ \\
$\mathrm{C} 2$ & $0.47123(10)$ & $0.27726(10)$ & $0.6889(3)$ & $0.0612(7)$ \\
$\mathrm{H} 2 \mathrm{~A}$ & 0.459150 & 0.293892 & 0.775102 & $0.092^{*}$ \\
$\mathrm{H} 2 \mathrm{~B}$ & 0.468058 & 0.241200 & 0.726620 & $0.092^{*}$ \\
$\mathrm{H} 2 \mathrm{C}$ & 0.446510 & 0.269637 & 0.594458 & $0.092^{*}$ \\
$\mathrm{C} 3$ & $0.55665(12)$ & $0.29361(11)$ & $0.5140(3)$ & $0.0634(7)$ \\
$\mathrm{H} 3 \mathrm{~A}$ & 0.551638 & 0.257044 & 0.553954 & $0.095^{*}$ \\
$\mathrm{H} 3 \mathrm{~B}$ & 0.597504 & 0.320235 & 0.493279 & $0.095^{*}$ \\
$\mathrm{H} 3 \mathrm{C}$ & 0.534860 & 0.286951 & 0.413769 & $0.095^{*}$ \\
$\mathrm{C} 4$ & $0.54001(9)$ & $0.37468(9)$ & $0.5772(2)$ & $0.0439(5)$ \\
$\mathrm{C} 5$ & $0.54464(10)$ & $0.41762(9)$ & $0.5145(2)$ & $0.0458(5)$ \\
$\mathrm{C} 6$ & $0.55281(9)$ & $0.46950(9)$ & $0.4317(2)$ & $0.0407(5)$ \\
$\mathrm{C} 7$ & $0.51138(9)$ & $0.46599(9)$ & $0.3192(2)$ & $0.0424(5)$ \\
$\mathrm{H} 7$ & 0.477559 & 0.430184 & 0.300298 & $0.051^{*}$ \\
$\mathrm{C} 8$ & $0.52018(9)$ & $0.51543(9)$ & $0.2351(2)$ & $0.0441(5)$ \\
$\mathrm{H} 8$ & 0.492523 & 0.513284 & 0.159933 & $0.053^{*}$ \\
$\mathrm{C} 9$ & $0.57045(9)$ & $0.56768(9)$ & $0.2648(2)$ & $0.0416(5)$ \\
C10 & $0.61185(10)$ & $0.57274(9)$ & $0.3773(3)$ & $0.0515(6)$ \\
$\mathrm{H} 10$ & 0.645262 & 0.608821 & 0.396842 & $0.062^{*}$ \\
$\mathrm{C} 11$ & $0.60276(10)$ & $0.52332(10)$ & $0.4602(3)$ & $0.0509(6)$ \\
$\mathrm{H} 11$ & 0.630422 & 0.526000 & 0.536242 & $0.061^{*}$ \\
& & & &
\end{tabular}

Atomic displacement parameters $\left(\AA^{2}\right)$

\begin{tabular}{lllllll}
\hline & $U^{11}$ & $U^{22}$ & $U^{33}$ & $U^{12}$ & $U^{13}$ & $U^{23}$ \\
\hline O1 & $0.0636(10)$ & $0.0378(8)$ & $0.0474(8)$ & $0.0216(7)$ & $-0.0238(7)$ & $-0.0036(6)$ \\
O2 & $0.0870(14)$ & $0.0812(13)$ & $0.0791(12)$ & $0.0450(11)$ & $-0.0075(11)$ & $0.0315(10)$ \\
O3 & $0.0734(13)$ & $0.0474(10)$ & $0.1082(15)$ & $0.0254(10)$ & $0.0056(11)$ & $0.0178(10)$ \\
N1 & $0.0592(12)$ & $0.0508(12)$ & $0.0661(13)$ & $0.0324(11)$ & $0.0118(10)$ & $0.0164(9)$ \\
C1 & $0.0463(11)$ & $0.0376(10)$ & $0.0322(9)$ & $0.0206(9)$ & $-0.0083(8)$ & $-0.0026(8)$ \\
C2 & $0.0501(14)$ & $0.0552(14)$ & $0.0690(15)$ & $0.0191(12)$ & $-0.0049(11)$ & $0.0064(11)$ \\
C3 & $0.0898(19)$ & $0.0674(16)$ & $0.0493(13)$ & $0.0514(15)$ & $-0.0007(12)$ & $-0.0056(11)$ \\
C4 & $0.0518(12)$ & $0.0460(12)$ & $0.0365(10)$ & $0.0264(10)$ & $-0.0029(9)$ & $0.0014(9)$ \\
C5 & $0.0577(13)$ & $0.0484(12)$ & $0.0364(10)$ & $0.0303(11)$ & $0.0001(9)$ & $0.0009(9)$
\end{tabular}




\begin{tabular}{|c|c|c|c|c|c|c|}
\hline C6 & $0.0535(12)$ & $0.0444(11)$ & $0.0311(9)$ & $0.0297(10)$ & $0.0052(8)$ & $0.0026(8)$ \\
\hline $\mathrm{C} 7$ & $0.0452(11)$ & $0.0423(11)$ & $0.0400(10)$ & $0.0223(10)$ & $0.0024(9)$ & $0.0009(8)$ \\
\hline C8 & $0.0480(12)$ & $0.0543(13)$ & $0.0379(10)$ & $0.0317(11)$ & $0.0011(9)$ & $0.0045(9)$ \\
\hline C9 & $0.0486(12)$ & $0.0431(11)$ & $0.0413(10)$ & $0.0291(10)$ & $0.0088(9)$ & $0.0080(8)$ \\
\hline $\mathrm{C} 10$ & $0.0491(13)$ & $0.0422(12)$ & $0.0598(13)$ & $0.0203(10)$ & $-0.0055(10)$ & $-0.0006(10)$ \\
\hline C11 & $0.0566(14)$ & $0.0538(13)$ & $0.0468(11)$ & $0.0310(11)$ & $-0.0109(10)$ & $-0.0005(10)$ \\
\hline
\end{tabular}

Geometric parameters $\left(\AA,{ }^{o}\right)$

\begin{tabular}{|c|c|c|c|}
\hline $\mathrm{O} 1-\mathrm{C} 1$ & $1.424(2)$ & $\mathrm{C} 3-\mathrm{H} 3 \mathrm{C}$ & 0.9600 \\
\hline $\mathrm{O} 1-\mathrm{H} 1 \mathrm{O}$ & 0.8200 & $\mathrm{C} 4-\mathrm{C} 5$ & $1.189(3)$ \\
\hline $\mathrm{O} 2-\mathrm{N} 1$ & $1.221(3)$ & $\mathrm{C} 5-\mathrm{C} 6$ & $1.438(3)$ \\
\hline $\mathrm{O} 3-\mathrm{N} 1$ & $1.219(2)$ & $\mathrm{C} 6-\mathrm{C} 11$ & $1.387(3)$ \\
\hline $\mathrm{N} 1-\mathrm{C} 9$ & $1.466(3)$ & $\mathrm{C} 6-\mathrm{C} 7$ & $1.390(3)$ \\
\hline $\mathrm{C} 1-\mathrm{C} 4$ & $1.471(3)$ & $\mathrm{C} 7-\mathrm{C} 8$ & $1.382(3)$ \\
\hline $\mathrm{C} 1-\mathrm{C} 2$ & $1.516(3)$ & $\mathrm{C} 7-\mathrm{H} 7$ & 0.9300 \\
\hline $\mathrm{C} 1-\mathrm{C} 3$ & $1.523(3)$ & $\mathrm{C} 8-\mathrm{C} 9$ & $1.371(3)$ \\
\hline $\mathrm{C} 2-\mathrm{H} 2 \mathrm{~A}$ & 0.9600 & $\mathrm{C} 8-\mathrm{H} 8$ & 0.9300 \\
\hline $\mathrm{C} 2-\mathrm{H} 2 \mathrm{~B}$ & 0.9600 & $\mathrm{C} 9-\mathrm{C} 10$ & $1.376(3)$ \\
\hline $\mathrm{C} 2-\mathrm{H} 2 \mathrm{C}$ & 0.9600 & $\mathrm{C} 10-\mathrm{C} 11$ & $1.375(3)$ \\
\hline $\mathrm{C} 3-\mathrm{H} 3 \mathrm{~A}$ & 0.9600 & $\mathrm{C} 10-\mathrm{H} 10$ & 0.9300 \\
\hline $\mathrm{C} 3-\mathrm{H} 3 \mathrm{~B}$ & 0.9600 & $\mathrm{C} 11-\mathrm{H} 11$ & 0.9300 \\
\hline $\mathrm{C} 1-\mathrm{O} 1-\mathrm{H} 1 \mathrm{O}$ & 109.5 & $\mathrm{H} 3 \mathrm{~B}-\mathrm{C} 3-\mathrm{H} 3 \mathrm{C}$ & 109.5 \\
\hline $\mathrm{O} 3-\mathrm{N} 1-\mathrm{O} 2$ & $123.3(2)$ & $\mathrm{C} 5-\mathrm{C} 4-\mathrm{C} 1$ & $175.7(2)$ \\
\hline $\mathrm{O} 3-\mathrm{N} 1-\mathrm{C} 9$ & $118.5(2)$ & $\mathrm{C} 4-\mathrm{C} 5-\mathrm{C} 6$ & $176.5(2)$ \\
\hline $\mathrm{O} 2-\mathrm{N} 1-\mathrm{C} 9$ & $118.2(2)$ & $\mathrm{C} 11-\mathrm{C} 6-\mathrm{C} 7$ & $119.25(18)$ \\
\hline $\mathrm{O} 1-\mathrm{C} 1-\mathrm{C} 4$ & $106.76(15)$ & $\mathrm{C} 11-\mathrm{C} 6-\mathrm{C} 5$ & $120.46(18)$ \\
\hline $\mathrm{O} 1-\mathrm{C} 1-\mathrm{C} 2$ & $109.11(16)$ & $\mathrm{C} 7-\mathrm{C} 6-\mathrm{C} 5$ & $120.27(19)$ \\
\hline $\mathrm{C} 4-\mathrm{C} 1-\mathrm{C} 2$ & $110.61(18)$ & $\mathrm{C} 8-\mathrm{C} 7-\mathrm{C} 6$ & $120.36(19)$ \\
\hline $\mathrm{O} 1-\mathrm{C} 1-\mathrm{C} 3$ & $110.10(17)$ & $\mathrm{C} 8-\mathrm{C} 7-\mathrm{H} 7$ & 119.8 \\
\hline $\mathrm{C} 4-\mathrm{C} 1-\mathrm{C} 3$ & $108.98(16)$ & $\mathrm{C} 6-\mathrm{C} 7-\mathrm{H} 7$ & 119.8 \\
\hline $\mathrm{C} 2-\mathrm{C} 1-\mathrm{C} 3$ & $111.20(18)$ & $\mathrm{C} 9-\mathrm{C} 8-\mathrm{C} 7$ & $118.75(18)$ \\
\hline $\mathrm{C} 1-\mathrm{C} 2-\mathrm{H} 2 \mathrm{~A}$ & 109.5 & $\mathrm{C} 9-\mathrm{C} 8-\mathrm{H} 8$ & 120.6 \\
\hline $\mathrm{C} 1-\mathrm{C} 2-\mathrm{H} 2 \mathrm{~B}$ & 109.5 & $\mathrm{C} 7-\mathrm{C} 8-\mathrm{H} 8$ & 120.6 \\
\hline $\mathrm{H} 2 \mathrm{~A}-\mathrm{C} 2-\mathrm{H} 2 \mathrm{~B}$ & 109.5 & $\mathrm{C} 8-\mathrm{C} 9-\mathrm{C} 10$ & $122.25(18)$ \\
\hline $\mathrm{C} 1-\mathrm{C} 2-\mathrm{H} 2 \mathrm{C}$ & 109.5 & $\mathrm{C} 8-\mathrm{C} 9-\mathrm{N} 1$ & $118.80(18)$ \\
\hline $\mathrm{H} 2 \mathrm{~A}-\mathrm{C} 2-\mathrm{H} 2 \mathrm{C}$ & 109.5 & $\mathrm{C} 10-\mathrm{C} 9-\mathrm{N} 1$ & $118.95(19)$ \\
\hline $\mathrm{H} 2 \mathrm{~B}-\mathrm{C} 2-\mathrm{H} 2 \mathrm{C}$ & 109.5 & $\mathrm{C} 11-\mathrm{C} 10-\mathrm{C} 9$ & $118.6(2)$ \\
\hline $\mathrm{C} 1-\mathrm{C} 3-\mathrm{H} 3 \mathrm{~A}$ & 109.5 & $\mathrm{C} 11-\mathrm{C} 10-\mathrm{H} 10$ & 120.7 \\
\hline $\mathrm{C} 1-\mathrm{C} 3-\mathrm{H} 3 \mathrm{~B}$ & 109.5 & $\mathrm{C} 9-\mathrm{C} 10-\mathrm{H} 10$ & 120.7 \\
\hline $\mathrm{H} 3 \mathrm{~A}-\mathrm{C} 3-\mathrm{H} 3 \mathrm{~B}$ & 109.5 & $\mathrm{C} 10-\mathrm{C} 11-\mathrm{C} 6$ & $120.79(19)$ \\
\hline $\mathrm{C} 1-\mathrm{C} 3-\mathrm{H} 3 \mathrm{C}$ & 109.5 & $\mathrm{C} 10-\mathrm{C} 11-\mathrm{H} 11$ & 119.6 \\
\hline $\mathrm{H} 3 \mathrm{~A}-\mathrm{C} 3-\mathrm{H} 3 \mathrm{C}$ & 109.5 & $\mathrm{C} 6-\mathrm{C} 11-\mathrm{H} 11$ & 119.6 \\
\hline $\mathrm{C} 11-\mathrm{C} 6-\mathrm{C} 7-\mathrm{C} 8$ & $0.7(3)$ & $\mathrm{O} 3-\mathrm{N} 1-\mathrm{C} 9-\mathrm{C} 10$ & $-9.2(3)$ \\
\hline $\mathrm{C} 5-\mathrm{C} 6-\mathrm{C} 7-\mathrm{C} 8$ & $-177.66(17)$ & $\mathrm{O} 2-\mathrm{N} 1-\mathrm{C} 9-\mathrm{C} 10$ & $170.3(2)$ \\
\hline $\mathrm{C} 6-\mathrm{C} 7-\mathrm{C} 8-\mathrm{C} 9$ & $0.2(3)$ & $\mathrm{C} 8-\mathrm{C} 9-\mathrm{C} 10-\mathrm{C} 11$ & $1.2(3)$ \\
\hline
\end{tabular}




\begin{tabular}{llll}
$\mathrm{C} 7-\mathrm{C} 8-\mathrm{C} 9-\mathrm{C} 10$ & $-1.2(3)$ & $\mathrm{N} 1-\mathrm{C} 9-\mathrm{C} 10-\mathrm{C} 11$ & $-178.21(19)$ \\
$\mathrm{C} 7-\mathrm{C} 8-\mathrm{C} 9-\mathrm{N} 1$ & $178.28(17)$ & $\mathrm{C} 9-\mathrm{C} 10-\mathrm{C} 11-\mathrm{C} 6$ & $-0.3(3)$ \\
$\mathrm{O} 3-\mathrm{N} 1-\mathrm{C} 9-\mathrm{C} 8$ & $171.3(2)$ & $\mathrm{C} 7-\mathrm{C} 6-\mathrm{C} 11-\mathrm{C} 10$ & $-0.7(3)$ \\
$\mathrm{O} 2-\mathrm{N} 1-\mathrm{C} 9-\mathrm{C} 8$ & $-9.2(3)$ & $\mathrm{C} 5-\mathrm{C} 6-\mathrm{C} 11-\mathrm{C} 10$ & $177.72(19)$ \\
\hline
\end{tabular}

Hydrogen-bond geometry $\left(\AA,{ }^{\circ}\right)$

\begin{tabular}{lllll}
\hline$D-\mathrm{H} \cdots A$ & $D-\mathrm{H}$ & $\mathrm{H} \cdots A$ & $D \cdots A$ & $D-\mathrm{H} \cdots A$ \\
\hline $\mathrm{O} 1-\mathrm{H} 1 O \cdots \mathrm{O} 1^{\mathrm{i}}$ & 0.82 & 1.87 & $2.682(2)$ & 173 \\
$\mathrm{C} 10-\mathrm{H} 10 \cdots \mathrm{O} 3^{\mathrm{ii}}$ & 0.93 & 2.67 & $3.548(3)$ & 157 \\
$\mathrm{C} 11-\mathrm{H} 11 \cdots \mathrm{O} 2^{\mathrm{iii}}$ & 0.93 & 2.68 & $3.467(3)$ & 143 \\
\hline
\end{tabular}

Symmetry codes: (i) $x-y+1 / 3, x-1 / 3,-z+5 / 3$; (ii) $-x+y+2 / 3,-x+4 / 3, z+1 / 3$; (iii) $-y+4 / 3, x-y+2 / 3, z+2 / 3$. 